\title{
Volatilities in Market Shares through Financial Fundamentals for Global Automobile Industry
}

\begin{abstract}
The proposition defined for this study is investigating the volatile behavior of automobile market share of top manufacturing nations in the presence of financial fundamentals; the time series data of market shares of the top 26 automobile manufacturing industry nations from 2002-2014 were calculated from the collected data of automotive sales of stated nations while stated automotive sales data were collected from the data stream $(\mathrm{EIKON})$ whereas, the change in closing shares prices and trading volume of stocks (financial fundamentals) for the same stated period of these nations were collected from the Yahoo! Finance. The GARCH 1,1 process was used and the findings confirmed that there is no GARCH 1,1 process in any of the given series as the ARCH and GARCH terms are found insignificant in the presence of stated conditional variables. Therefore, lagged autoregressive investigation for this study revealed that econometrical volatilities in the stated market shares defined in previous time grid (lag 01) do not predict volatility significantly in a current time grid for all the nations.
\end{abstract}

Keywords: : Volatilities in market shares of automobiles industry, change in closing shares / prices of stocks, trading volume of stocks, ARCH term, GARCH term.

\section{Introduction}

The automobile industry is one of the leading economic drivers of the world; it holds a great chunk of expansion, strength and cohesion to the micro-economic zone and that is why the automobile industry is acclaimed as one of the elements in building and fostering a nation (Klink, Mathur, Kidambi \& Sen, 2013).. Enabling Research, Innovation \& Development, accelerating economic growth, bringing governments' revenue, generating employment opportunities are some of the positive shifts that come into motion due to the automobile industry operations (Klink, Mathur, Kidambi \& Sen, 2013). Taking the USA automobile industry as an example, it was found that 820,000 employees were hired in year 2013 and Research, Development and Innovation unit was given an investment for 18 billion US Dollars due to its own significance and importance to the industry growth (Benka \& Krist, 2014). Globally, the Gross Domestic Product 
outcome of the automobile industry is 3\% and GDP for progressing nations like China \& India in this industry is around 7\% or more (Klink, Mathur, Kidambi \& Sen, 2013), while for these stated nations, stock market influences its world automobile market shares (Mazzucato \& Semmler, 2002).

\section{Market Share in relevance to Automobile Industry:}

In the automobile industry, market share provides an ample view about the automobile firms' market leader with regards to market segmentations and in greater detail it identifies the aggregate production, manufacturing cost for firms', which attain a higher market share and indeed in this established industry of existing automobile giants since decades, it is extremely difficult to gain one's market share. Like any other industry, automobile industry also has to carry out contingency planning and right marketing strategies, strategic program etc to gain the market share. Hence, the business, marketing and development managers usually tap unsatisfactory market position to gain volume profits and profitability (Fogg, 1974).

In the names of auto giants, General Motors is one name; it has the one of the famous success stories in the automobile industry and is one of the oldest automobile organizations. This auto brand has all the benefits of enjoying high market share and growing further. Despite of a certain

period downfall, General Motors has stood up again and tops the list in the auto industry and operates in 120 countries. It provides better territorial aspect in comparison to its competitors.

They have merged brilliantly in the global automobile industry, they also have a sister concern company named General Motors Financial, which offers financial options for owning cars. This giant auto brand has well-known car brands such as Chevrolet, GMC, Buick and Cadillac. This firm has earned 1.19 per share, which is higher than the estimated amount of 83 cents (Darell, 2015).

The market share of small cars is increasing day by day and there are chances of an increase of market share of these cars purchase from 47\% (year 2014) to $51 \%$ (year 2015). Hence, Overall sales and market share of the auto industry would shake -up to $3.6 \%$ (690, 724 units). Mazda auto brand is emerging to gain sales in year 2015 in the foreign automobile market. It has launched new cars in this year only. After Mazda, Toyota takes the market space in a way that their sales will stay nominal. Toyota would not launch any new cars but has launched new car 
models locally. Internationally, it would also focus on its existing brands besides Camry model, which are not the focus this year. Furthermore, the international brands will resume operating to sell their auto brands in the local markets (Tan, 2015).

\section{Sales and Market share}

There are some dominant automobile brands in the industry, which have been dominating since years and bringing revolution with time. When we talk about market share, it's quite highly concentrated. The giants in the automobile sector have $80 \%$ of the market share in terms of the

global production and U.S. has been dominant in terms of importing $90 \%$ of the vehicles (Zacks, 2014).

According to the latest research carried out by Zacks(2014), General Motors company (GM) market share was the highest with $18.7 \%$ in the U.S., Ford Motor Co. (F) with $15.9 \%$ market share, Toyota Motors Corp. ${ }^{\text {TM }}$ with $15.1 \%$ market share, Chrysler-Fiat with $11.3 \%$ market share. Honda Motor Co. (HMC) has 9\% market share and Nissan Motor Co. (NSANY) has 7.8\% market share.

There are upheavals in this industry in terms of sales and overall market share; an example is of year 2012, Toyota took the sales market of General Motors by have vehicles sales of 9.75 million globally. Germany's Volkswagen (VLKAY) came third in vehicles sales of 9.07 million for the year. Toyota's sales victory was due its inspiring product variants and marketing inventiveness. Toyota in year 2011 has already lost its leading position to GM after attaining the same position in year 2008. The reason behind Toyota's position fall was due to safety concerns as well as adverse impact from natural disasters, which occurred in Thailand and Japan in year 2011. Still, Toyota is adamant to increase its market share and sales growth again in different markets such as the emerging markets and non U.S. markets.

In the automobile industry market share provides an ample view about the automobile firms' market leader in various market segmentations. In greater detail it identifies the aggregate production, manufacturing cost for firms', which attain a higher market share and indeed in this established industry of existing automobile giants since decades, it is extremely difficult to gain one's market share. Like any other industry, automobile industry also has to carry out contingency planning and right marketing strategies, strategic program etc to gain the market share. 
Hence, the business, marketing and development managers usually tap unsatisfactory market position to gain volume profits and profitability (Fogg, 1974).

Market share as represented by the sales of a particular industry, studying the US auto sector revealed sales, which were much better in year 2000 then 2011. The reasons behind the sales fall was due to the fall in total demand and long-term decline in the market share (Wething \& Scott, 2012).

In the names of auto giants, General Motors is one name; it has the one of the famous success stories in the automobile industry and is one of the oldest automobile organizations. This auto brand has all the benefits of enjoying high market share and growing further. Despite of a certain period downfall, General Motors has stood up again and tops the list in the auto industry and operates in 120 countries. It provides better territorial aspect in comparison to its competitors. They have merged brilliantly in the global automobile industry, they also have a sister concern company named General Motors Financial, which offers financial options for owning cars. This giant auto brand has well-known car brands such as Chevrolet, GMC, Buick and Cadillac. This firm has earned 1.19 per share, which is higher than the estimated amount of 83 cents (Darell, 2015).

The market share of small cars is increasing day by day and there are chances of an increase of market share of these cars purchase from 47\% (year 2014) to $51 \%$ (year 2015 ). Hence, Overall sales and market share of the auto industry would scale up to $3.6 \%$ (690, 724 units).

Mazda auto brand is emerging to gain sales in year 2015 in the foreign automobile market. It has launched new cars in this year only. After Mazda, Toyota takes the market space in a way that their sales will stay nominal. Toyota would not launch any new cars but has launched new car models locally. Internationally, it would also focus on its existing brands besides Camry model, which are not the focus this year. Furthermore, the international brands will resume operating to sell their auto brands in the local markets (Tan, 2015).

\section{Opportunities to gain market share}

In order to lead in the automobiles industry, a firm needs to be readily competitive, design vehicles according to the consumers pocket and need whether it's mature or emerging market. Firms also need to manufacture the vehicles at a low-cost using the most superior technolo- 
gy. For instance, Ford uses the 'One manufacturing' strategy, which primarily aims at producing various models from the different plants around the world in regulation to save manufacturing costs and quick adaptation to alterations in consumer choices. Ford's manufacturing prediction is of 4.5 models on its each plant by 2015, starting from 3.6 models presently.

Different insights are being used by the automakers to attract their consumers to buy their brand of car. Automakers are paying attention to the optional features like to save money on gas even on small cars. Focusing on optional features is helping automakers to balance lower profit margins for small cars comparative to large trucks.

Moreover, automakers production facilities have been moved from high-cost regions such as European Union and North America to low-cost regions such as South America, China and India. It has been assessed that South America and China alone have projected 50\% growth in light vehicles in the global auto industry from 2008 to 2015.

Government has a significant role in the auto industry. The energy and environmental regulations and policies by the government of all the major countries are to shape the future of the auto industry. In order to improve the fuel economy standard of the vehicles and light trucks to 54/5 miles per gallon (mpg( by 2025, 13 automakers (Ford, GM, Chrysler, BMW, Honda, Hyundai, Land Rover, Kia, Mazda, Nissan, Mitsubishi, Toyota and Volvo) have signed letters of commitment with the U.S. government.

The new fuel standard will save around 12 billion barrels of oil and restrict oil use 2.2 oil barrels per day, which is the half of the oil taken by the U.S from OPEC countries on regular basis. It would also reduce carbon pollution.

\section{Stock Markets}

Looking at the East, South, and South-East Asian markets a wide range of variety are found in terms of both the business cultures and economic development as a whole. Whereby Indonesia is the biggest economy in the South-Eastern region and China is the biggest economy all of East Asia; Japan and Korea, on the other hand, are the only Asian country that are a part of the OECD and rank above the OECD average in terms of GDP (PPP) per capita (OECD Stat, 2015). Similarly, in the South Asia, India is the biggest economy. The three regions are interlinked through various forms of regional organization and trade agreements, the most prominent 
of them being the SAARC, ASEAN plus SIX (the proposed RECEP), TPP, and FTAAP; all of these efforts as with the trends of globalization allow for an ever more increasing volumes of trade and interdependence as between the countries of the region and with the rest of the world.

The regional countries are also at drastically different stages of development, whereby most of the SAARC and ASEAN countries are emerging economies, while China and South Korea are the two of the most bullish economies of the world; India on the other hand is observed to have a rapidly growing population, so much so that India is forecasted to leap over China by the year 2022, while China's population will continue towards a declining trend (United Nations, 2015); contrarily, Japan's economy has been stagnant for the past two decades, also known as the Lost Decades, while the country undergoes an increasingly ageing population.

Kurihara and Nezu (2006) investigated the drastic economic policies in Japan of zero interestrate and its impact on the stock prices, the study notes that that quantitative easing and exchangerate fluctuations in Japan did not have any impact on the country's stock-prices, while instead the changes in stock-prices of the US companies have had a significant impact on the Japanese stock prices. Due to close integration and access to the financial markets investors from mature and stagnant markets have been looking at other investment diversifying opportunities; Seth and Sharma (2015) studied the markets of 13 world markets including India, China, Hong Kong, Indonesia, Malaysia, Japan, Singapore, South Korea, Taiwan, Israel, Pakistan, and the US, the study utilizes data ranging Jan 2001 to Dec 2010 in-order to examine the pre and post financial crisis and the changes induced across the stock-markets and significant co-movements. The study has run various tests, amongst with it has also used the GARCH $(1,1)$ model to test for weakform marker efficiency, whereby a significant clustering is identified as across the studied stockmarkets, thereby identifying that the markets have a rather strong-form efficiency and that the markets allow for super-normal returns for investors with information and discretion - similar findings were also reached by Shamsuddin and Kim (2008). Similarly, the markets are furthermore found to be significantly co-related in the long run, making the prospects of diversification in regional markets a rather unprofitable approach. The study notes that although the markets do not become weaker or stronger in their efficiency forms as before or after the financial crisis, yet the markets have significantly lost some degree of integration. 
Similarly, Gooijer and Sivaraja (2008) examine 11 different economies including, Hong Kong, Singapore, Japan, Germany, US, and UK (which all together represent almost half of the world equity) and India, Sri Lanka, Malaysia, South Korea, and Taiwan (all of which at the time were emerging economies). The study analyzes stock-market data ranging 1987 - 2006, and finds that the Asian markets have become more integrated with the world's financial leaders as after the Asian financial crisis of 1997, also noting that the co-movement and causal linkages have strengthened as after the crisis. Siddiqui (2009a) and Mukherjee and Mishra (2007) are similarly led to conclude that the volatility spillovers between the Asian countries of Thailand, Korea, Singapore, Hong Kong, and India are rather significant, whereby information transfers are almost instantaneous and are bi-directional in nature. Similarly, an earlier study analyzing 23 various economies found that regional economies tend to be more closely integrated than with countries with significant time-zone differential or distance. Batareddy, Gopalaswamy, Huang (2012) while examining the emerging (India, South Korea, Taiwan, and China) and developed (Japan and US) markets find that there is a long-run integration between both the studied groups and that the Asian markets are individually more integrated with the US market than with their regional emerging markets. Nonetheless, the level of integration as between the regional markets has increased over the years.

Yang, Kolari, and Sutanto (2004) while studying the Latin American and Asian markets identify those economic and financial crises can significantly alter the levels of integration as between the individual stock-markets. Similarly, Corhay, Rad, and Urbain (1995), Masih and Masih (1997) and Bessler and Yang (2003), while keeping in view the Asian markets, note that the regional stock-markets are significantly co-integrated in the long-run, whereby short-run shocks and change in trends are rather temporary and that market forces, which essentially comprise of trading-investors and government policies, make the various individual stock-markets follow the same long-run trend.

Kim (2005) analyzed the stock markets of Hong Kong, Singapore, Japan, Australia, and USA. The study notes that stock-market inter-linkages became more strengthened as after the Asian financial crisis of 1997. The study moreover identifies significant spillover of US market-volatil- 
ity into the Asian markets; while spillover from the Japan markets is identified to be comparatively weaker.

Daly (2003) examined the emerging stock-markets of Asia, namely Thailand, Malaysia, Singapore, Indonesia, and Philippines, and the developed world markets of US, Australia, and Germany, finding that inter-market dependencies across both the group of markets significantly increased in the wake of post Asian financial crisis period.

Sharma and Bodla, (2011) examined the integration between the markets of Sri Lanka, India, and Pakistan by analyzing data ranging 2003-2010. The study uses the Granger's causality and VAR model and finds that the Indian stock-markets influence the markets of both Pakistan and Srilan$\mathrm{ka}$, while the reverse is not true.

A number of studies identified an absence of integration between and amongst the various regional stock markets (predominantly the Asian markets) and their linkages with the developed world markets (Menon, Subha, \& Sagaran, 2009; Hoque, 2007; Bodla \& Turan, 2006; Nath \& Verma, 2003; Worthington, Katsuura, \& Higgs, 2003; Yang, Kolari, \& Min, 2003 ; Sharma \& Wongbangpo, 2002; Bala \& Mukund, 2001; Pan, Liu, \& Roth, 1999; Elyasiani, Perera, \& Puri, 1998; Chaudhuri, 1997; Chan, Gup, \& Pan, 1997).

Yia, Heng, and Wong (2009) examine the China stock-markets with reference to its integration with the Hong Kong (HK) and USA markets, while observing the historical market trends ranging across the Asian financial crisis of 1997 and the international financial meltdown of 2008. The study results lead to conclusion that the Chinese markets have fractional linkages with US and $\mathrm{HK}$, also that the Chinese markets are more strongly integrated with the HK markets as compared to the US markets. The study notes that the results of volatility spillovers are nonetheless unclear and that no significant difference in cause and response is found across the two financial crises.

The North American stock markets are perhaps the most relevant on the global financial stage; whereby NAFTA has further strengthened the integration among the North American stock markets by allowing more flow of trade across the region and hence creating ever more interdepen- 
dencies in production processes and supply-chain networks. As a result of greater trade amongst the signatory countries, NAFTA is speculated to have aligned stock-return trends; which is nonetheless noted to be especially beneficial for Mexico, allowing emerging traders to now have access to ever bigger markets of the US and Canada (Martin and Wood, 1996).

The American stock-markets are most relevant to such investigation as many of the researchfindings suggest that the American stock markets (esp. NASDAQ and NYSE) are the biggest stock-market information producers, and that these markets constitute a large percent of the "world-factor" that similarly impacts all the world-markets inducing a global co-movement in stock-markets. Eun and Shim (1989) contend the same identifying US has the most important and biggest financial information producer, all of which eventually impacts the stock markets worldwide; the study utilizes vector auto regression (VAR) to determine price transmissions across the stock markets of nine countries; whereby the study results suggest high degree of linkages in daily returns across the markets studied.

Hamao et al. (1990) reports similar findings suggesting that the American stock-markets (NASDAQ and NYSE) are perhaps the most influential markets, noting that the American stock-market returns were able to explain market-returns in countries like Canada, UK, Germany, and Japan. Scholl hammer and Sand (1985) identify the same while investigating daily stock prices in-order to track co-movements between the US and other major European markets (including UK, Germany, Switzerland, France, Italy, and the Netherlands); the study finds a significant tendency of co-movement as between the US and the European markets, except for the case of Italy and France. 
Lee (2011) found that the US market returns paired with the covariance of a stock's liquidity greatly determine the level of expected returns on a stock, whereby the case holds true especially in the developed markets. The study also notes that global liquidity risk tends to affect the domestic stocks more-so as compared to the domestic liquidity risk, this too was found to especially hold true for the developed markets perhaps due to the relative internationalization, openness, and transparency of these markets. Nonetheless, the US stock market returns have been identified as leading the world markets as under this study.

\section{Propositions and Hypotheses}

Table 1. Proposition and Hypotheses

\begin{tabular}{|c|c|c|c|}
\hline \multicolumn{4}{|c|}{$\begin{array}{l}\text { Proposition: Are the volatility in automobiles (Cars) total market share of the world (top auto- } \\
\text { mobile manufacturing countries) same in the presence of financial fundamentals (equity/ stock } \\
\text { markets)? }\end{array}$} \\
\hline \multicolumn{4}{|c|}{$\begin{array}{l}\text { Statement of Hypothesis 1: There is the volatility in the total market share of automobiles (cars) } \\
\text { of top automobile manufacturing countries in the presence of change in stock prices. }\end{array}$} \\
\hline H1: ARGENTINA & H8: GERMANY & H15: MEXICO & H22: TAIWAN \\
\hline H2: AUSTRALIA & H9: HUNGARY & H16: POLAND & H23: TURKEY \\
\hline H3: BRAZIL & H10: INDIA & H17: ROMANIA & H24: UKRAINE \\
\hline H4: CANADA & H11: INDONESIA & H18: RUSSIA & $\begin{array}{l}\text { H25: UNITED KING- } \\
\text { DOM }\end{array}$ \\
\hline H5: CHINA & H12: ITALY & H19: SOUTH AFRICA & H26: UNITED STATES \\
\hline $\begin{array}{l}\text { H6: CZECH REPUB- } \\
\text { LIC }\end{array}$ & H13: JAPAN & H20: SOUTH KOREA & \\
\hline H7: FRANCE & H14: MALAYSIA & H21: SPAIN & \\
\hline \multicolumn{4}{|c|}{$\begin{array}{l}\text { Statement of Hypothesis 2: There is the volatility in the total market share of automobiles (cars) } \\
\text { of top automobile manufacturing countries in the presence of trading volume of stocks. }\end{array}$} \\
\hline H1: ARGENTINA & H8: GERMANY & H15: MEXICO & H22: TAIWAN \\
\hline
\end{tabular}




\begin{tabular}{|l|l|l|l|}
\hline H2: AUSTRALIA & H9: HUNGARY & H16: POLAND & H23: TURKEY \\
\hline H3: BRAZIL & H10: INDIA & H17: ROMANIA & H24: UKRAINE \\
\hline H4: CANADA & H11: INDONESIA & H18: RUSSIA & $\begin{array}{l}\text { H25: UNITED KING- } \\
\text { DOM }\end{array}$ \\
\hline H5: CHINA & H12: ITALY & H19: SOUTH AFRICA & H26: UNITED STATES \\
\hline $\begin{array}{l}\text { H6: CZECH REPUB- } \\
\text { LIC }\end{array}$ & H13: JAPAN & H20: SOUTH KOREA & \\
\hline H7: FRANCE & H14: MALAYSIA & H21: SPAIN & \\
\hline & \multicolumn{3}{|l}{} \\
\hline
\end{tabular}

\section{Data Description and Research Methodology}

The top automobile industry nations, which include ARGENTINA, AUSTRALIA, BRAZIL, CANADA, CHINA, CZECH REPUBLIC, FRANCE, GERMANY, HUNGARY, INDIA, INDONESIA, ITALY, JAPAN, MALAYSIA, MEXICO, POLAND, ROMANIA, RUSSIA, SOUTH AFRICA, SOUTH KOREA, SPAIN, TAIWAN, TURKEY, UKRAINE, UNITED KINGDOM, UNITED STATES were taken to investigate the proposition on the subject of volatility in the series of automobile market shares in the presence of the stock markets. The time series data of world market shares automobiles industry of the outlined nations from 2002-2014 were collected from the EIKON while the change in closing shares prices and trading volume of stocks for the same stated period were collected from the Yahoo finance. For investigating the framed proposition and two hypotheses, GARCH 1,1 process was deployed on all of the given series. The ARCH and GARCH terms of GARCH 1, 1 process was taken as the testing specifications and explaining terms for taking the decisions on all hypotheses.

Findings and Results for volatility in Automobile (Cars) total market share when conditional variables are change in stock price and trading volume.

Table 2. Findings and Results

Proposition: Are the volatility in automobiles (Cars) total market share of the world (top automobiles manufacturing countries) same in the presence of financial fundamentals (equity/ stock markets)? 
Statement of Hypothesis 1: There is the volatility in the total market share of automobiles (cars) of top automobile manufacturing countries in the presence of change in stock prices.

\begin{tabular}{|c|c|c|c|c|c|}
\hline \multirow[b]{2}{*}{ Country } & \multirow[b]{2}{*}{$\begin{array}{c}\text { Empirical } \\
\text { Conclusions }\end{array}$} & \multicolumn{2}{|c|}{ Explaining Term } & \multirow[b]{2}{*}{$\begin{array}{l}\text { Adj. R- } \\
\text { Squared }\end{array}$} & \multirow{2}{*}{$\begin{array}{c}\text { Conditional } \\
\text { Variable } \\
\text { (change in stock } \\
\text { price) }\end{array}$} \\
\hline & & $\begin{array}{l}\text { ARCH } \\
\text { (z-test) }\end{array}$ & $\begin{array}{c}\text { GARCH } \\
\text { (z-test) }\end{array}$ & & \\
\hline \multirow{3}{*}{ H1: Argentina } & \multirow{3}{*}{$\begin{array}{c}\text { No/Failed to } \\
\text { Accept }\end{array}$} & 0.1500 & 0.6000 & \multirow{3}{*}{0.5748} & $1.04 \mathrm{E}-12$ \\
\hline & & $(0.08225)$ & $(0.245818)$ & & $(0.0000943)$ \\
\hline & & No & No & & \\
\hline \multirow{3}{*}{ H2: Australia } & \multirow{3}{*}{$\begin{array}{c}\text { No/Failed to } \\
\text { Accept }\end{array}$} & 0.1500 & 0.6000 & \multirow{3}{*}{0.9430} & $-4.78 \mathrm{E}-13$ \\
\hline & & $(0.146784)$ & $(0.191477)$ & & $(-0.0000125)$ \\
\hline & & No & No & & \\
\hline \multirow{3}{*}{ H3: Brazil } & \multirow{3}{*}{$\begin{array}{c}\text { No/Failed to } \\
\text { Accept }\end{array}$} & 0.1500 & 0.6000 & \multirow{3}{*}{-0.0416} & $5.29 \mathrm{E}-13$ \\
\hline & & $(0.080917)$ & $(0.16472)$ & & $(0.000435)$ \\
\hline & & No & No & & \\
\hline \multirow{3}{*}{ H4: Canada } & \multirow{3}{*}{$\begin{array}{l}\text { No/Failed to } \\
\text { Accept }\end{array}$} & 0.1500 & 0.6000 & \multirow{3}{*}{0.2528} & $3.03 \mathrm{E}-13$ \\
\hline & & $(0.134601)$ & $(0.138162)$ & & $(0.00000704)$ \\
\hline & & No & No & & \\
\hline \multirow{3}{*}{ H5: China } & \multirow{3}{*}{$\begin{array}{c}\text { No/Failed to } \\
\text { Accept }\end{array}$} & 0.1500 & 0.6000 & \multirow{3}{*}{0.9653} & $3.38 \mathrm{E}-12$ \\
\hline & & $(0.130015)$ & $(0.332213)$ & & $(0.001705)$ \\
\hline & & No & No & & \\
\hline \multirow{3}{*}{$\begin{array}{l}\text { H6: Czech Repub- } \\
\text { lic }\end{array}$} & \multirow{3}{*}{$\begin{array}{c}\text { No/Failed to } \\
\text { Accept }\end{array}$} & 0.1500 & 0.6000 & \multirow{3}{*}{0.2531} & $6.11 \mathrm{E}-11$ \\
\hline & & $(0.128053)$ & $(0.154847)$ & & $(0.723266)$ \\
\hline & & No & No & & \\
\hline \multirow{3}{*}{ H7: France } & \multirow{3}{*}{$\begin{array}{c}\text { No/Failed to } \\
\text { Accept }\end{array}$} & 0.1500 & 0.6000 & \multirow{3}{*}{0.8879} & $2.42 \mathrm{E}-11$ \\
\hline & & $(0.134482)$ & $(0.127786)$ & & $(0.066806)$ \\
\hline & & No & No & & \\
\hline \multirow{3}{*}{ H8: Germany } & \multirow{3}{*}{$\begin{array}{c}\text { No/Failed to } \\
\text { Accept }\end{array}$} & 0.1500 & 0.6000 & \multirow{3}{*}{0.8102} & $5.36 \mathrm{E}-12$ \\
\hline & & $(0.117486)$ & $(0.091004)$ & & $(0.003339)$ \\
\hline & & No & No & & \\
\hline \multirow{3}{*}{ H9: Hungary } & \multirow{3}{*}{$\begin{array}{c}\text { No/Failed to } \\
\text { Accept }\end{array}$} & 0.1500 & 0.6000 & & $7.51 \mathrm{E}-12$ \\
\hline & & $(0.11738)$ & $(0.482192)$ & 0.5107 & $(0.011282)$ \\
\hline & & No & No & & \\
\hline & & 0.1500 & 0.6000 & & $1.94 \mathrm{E}-12$ \\
\hline
\end{tabular}




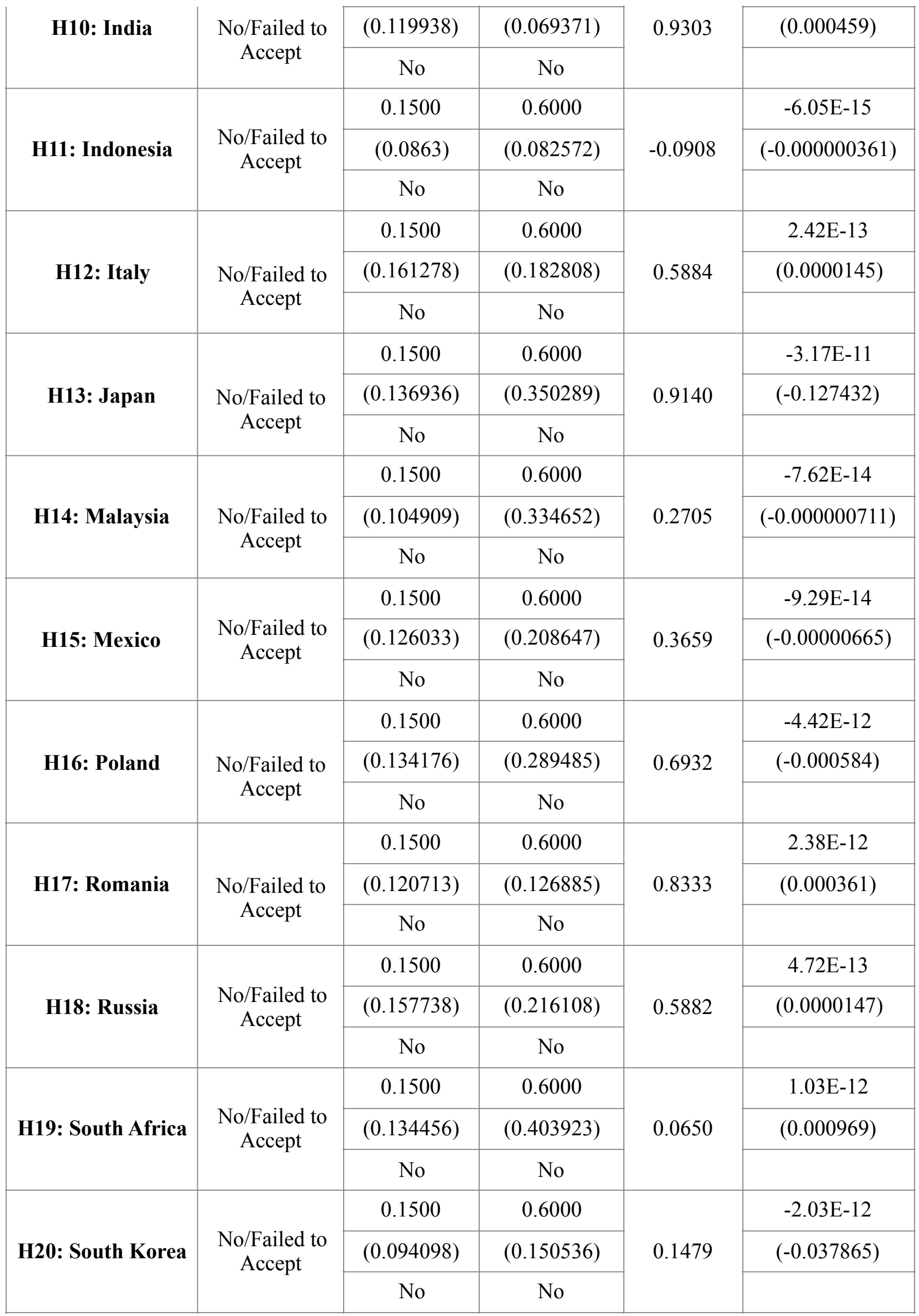




\begin{tabular}{|c|c|c|c|c|c|}
\hline \multirow{3}{*}{ H21: Spain } & \multirow{3}{*}{$\begin{array}{c}\text { No/Failed to } \\
\text { Accept }\end{array}$} & 0.1500 & 0.6000 & \multirow{3}{*}{0.8529} & $1.29 \mathrm{E}-11$ \\
\hline & & $(0.114786)$ & $(0.207672)$ & & $(0.137826)$ \\
\hline & & No & No & & \\
\hline \multirow{3}{*}{ H22: Taiwan } & \multirow{3}{*}{$\begin{array}{c}\text { No/Failed to } \\
\text { Accept }\end{array}$} & 0.1500 & 0.6000 & \multirow{3}{*}{0.4801} & $-2.72 \mathrm{E}-12$ \\
\hline & & $(0.184157)$ & $(0.186701)$ & & $(-0.007351)$ \\
\hline & & No & No & & \\
\hline \multirow{3}{*}{ H23: Turkey } & \multirow{3}{*}{$\begin{array}{c}\text { No/Failed to } \\
\text { Accept }\end{array}$} & 0.1500 & 0.6000 & \multirow{3}{*}{0.2722} & $-3.13 \mathrm{E}-12$ \\
\hline & & $(0.138352)$ & $(0.120669)$ & & $(-0.009293)$ \\
\hline & & No & No & & \\
\hline \multirow{3}{*}{ H24: Ukraine } & \multirow{3}{*}{$\begin{array}{c}\text { No/Failed to } \\
\text { Accept }\end{array}$} & 0.1500 & 0.6000 & \multirow{3}{*}{0.4421} & $-2.38 \mathrm{E}-12$ \\
\hline & & $(0.155416)$ & $(0.469309)$ & & $(-0.000552)$ \\
\hline & & No & No & & \\
\hline \multirow{3}{*}{$\begin{array}{l}\text { H25: United } \\
\text { Kingdom }\end{array}$} & \multirow{3}{*}{$\begin{array}{c}\text { No/Failed to } \\
\text { Accept }\end{array}$} & 0.1500 & 0.6000 & \multirow{3}{*}{0.5359} & $-4.57 \mathrm{E}-13$ \\
\hline & & $(0.119941)$ & $(0.198308)$ & & $(-0.0000803)$ \\
\hline & & No & No & & \\
\hline \multirow{3}{*}{$\begin{array}{l}\text { H26: United } \\
\text { States }\end{array}$} & \multirow{3}{*}{$\begin{array}{c}\text { No/Failed to } \\
\text { Accept }\end{array}$} & 0.1500 & 0.6000 & \multirow{3}{*}{0.8529} & $-9.53 E-13$ \\
\hline & & $(0.138539)$ & $(0.169737)$ & & $(-0.0000285)$ \\
\hline & & No & No & & \\
\hline
\end{tabular}

Statement of Hypothesis 2: There is the volatility in the total market share of automobiles (cars) of top automobiles manufacturing countries in the presence of trading volume of stocks.

\begin{tabular}{|c|c|c|c|c|c|}
\hline \multirow[b]{2}{*}{ Country } & \multirow{2}{*}{$\begin{array}{c}\text { Empirical } \\
\text { Conclusions }\end{array}$} & \multicolumn{2}{|c|}{ Explaining Term } & \multirow[b]{2}{*}{$\begin{array}{l}\text { Adj. R- } \\
\text { Squared }\end{array}$} & \multirow{2}{*}{$\begin{array}{c}\text { Conditional } \\
\text { Variable } \\
\text { (trading vol- } \\
\text { ume) }\end{array}$} \\
\hline & & $\begin{array}{l}\text { ARCH } \\
\text { (z-test) }\end{array}$ & $\begin{array}{c}\text { GARCH } \\
\text { (z-test) }\end{array}$ & & \\
\hline \multirow{3}{*}{ H1: Argentina } & \multirow{3}{*}{$\begin{array}{c}\text { No/Failed to } \\
\text { Accept }\end{array}$} & 0.1500 & 0.6000 & \multirow{3}{*}{0.9377} & $5.84 \mathrm{E}-13$ \\
\hline & & $(0.085961)$ & $(0.175059)$ & & $(0.0000243)$ \\
\hline & & No & No & & \\
\hline \multirow{4}{*}{ H2: Australia } & \multirow{3}{*}{$\begin{array}{c}\text { No/Failed to } \\
\text { Accept }\end{array}$} & 0.1500 & 0.6000 & \multirow{3}{*}{0.6501} & $-1.28 \mathrm{E}-12$ \\
\hline & & $(0.128461)$ & $(0.194987)$ & & $(-0.000105)$ \\
\hline & & No & No & & \\
\hline & & 0.1500 & 0.6000 & & $8.73 \mathrm{E}-13$ \\
\hline
\end{tabular}




\begin{tabular}{|c|c|c|c|c|c|}
\hline \multirow{3}{*}{ H3: Brazil } & \multirow{3}{*}{$\begin{array}{l}\text { No/Failed to } \\
\text { Accept }\end{array}$} & & & & \multirow{3}{*}{$(0.000469)$} \\
\hline & & $(0.151588)$ & $(0.334782)$ & 0.2405 & \\
\hline & & No & No & & \\
\hline \multirow{3}{*}{ H4: Canada } & \multirow{3}{*}{$\begin{array}{c}\text { No/Failed to } \\
\text { Accept }\end{array}$} & 0.1500 & 0.6000 & \multirow{3}{*}{-0.0760} & $-1.58 \mathrm{E}-13$ \\
\hline & & $(0.08983)$ & $(0.0791)$ & & $(-0.00000503)$ \\
\hline & & No & No & & \\
\hline \multirow{3}{*}{ H5: China } & \multirow{3}{*}{$\begin{array}{c}\text { No/Failed to } \\
\text { Accept }\end{array}$} & 0.1500 & 0.6000 & \multirow{3}{*}{0.9722} & $2.88 \mathrm{E}-12$ \\
\hline & & $(0.068518)$ & $(0.201651)$ & & $(0.001849)$ \\
\hline & & No & No & & \\
\hline \multirow{3}{*}{$\begin{array}{l}\text { H6: Czech Repub- } \\
\text { lic }\end{array}$} & \multirow{3}{*}{$\begin{array}{l}\text { No/Failed to } \\
\text { Accept }\end{array}$} & 0.1500 & 0.6000 & \multirow{3}{*}{0.5598} & $-1.96 \mathrm{E}-12$ \\
\hline & & $(0.180234)$ & $(0.151635)$ & & $(-0.000462)$ \\
\hline & & No & No & & \\
\hline \multirow{3}{*}{ H7: France } & \multirow{3}{*}{$\begin{array}{l}\text { No/Failed to } \\
\text { Accept }\end{array}$} & 0.1500 & 0.6000 & \multirow{3}{*}{0.3176} & $-3.85 \mathrm{E}-12$ \\
\hline & & $(0.058613)$ & $(0.058165)$ & & $(-0.001759)$ \\
\hline & & No & No & & \\
\hline \multirow{3}{*}{ H8: Germany } & \multirow{3}{*}{$\begin{array}{l}\text { No/Failed to } \\
\text { Accept }\end{array}$} & 0.1500 & 0.6000 & \multirow{3}{*}{0.5601} & $-7.17 \mathrm{E}-12$ \\
\hline & & $(0.089286)$ & $(0.175649)$ & & $(-0.001673)$ \\
\hline & & No & No & & \\
\hline \multirow{3}{*}{ H9: Hungary } & \multirow{3}{*}{$\begin{array}{l}\text { No/Failed to } \\
\text { Accept }\end{array}$} & 0.1500 & 0.6000 & \multirow{3}{*}{0.4520} & $1.83 \mathrm{E}-12$ \\
\hline & & $(0.153063)$ & $(0.298474)$ & & $(0.00053)$ \\
\hline & & No & No & & \\
\hline \multirow{3}{*}{ H10: India } & \multirow{3}{*}{$\begin{array}{l}\text { No/Failed to } \\
\text { Accept }\end{array}$} & 0.1500 & 0.6000 & \multirow{3}{*}{0.9228} & $8.59 \mathrm{E}-13$ \\
\hline & & $(0.093417)$ & $(0.09056)$ & & $(0.000243)$ \\
\hline & & No & No & & \\
\hline \multirow{3}{*}{ H11: Indonesia } & \multirow{3}{*}{$\begin{array}{c}\text { No/Failed to } \\
\text { Accept }\end{array}$} & 0.1500 & 0.6000 & \multirow{3}{*}{0.1994} & $-3.36 \mathrm{E}-13$ \\
\hline & & $(0.042449)$ & $(0.148287)$ & & $(-0.0000606)$ \\
\hline & & No & No & & \\
\hline \multirow{3}{*}{ H12: Italy } & \multirow{3}{*}{$\begin{array}{l}\text { No/Failed to } \\
\text { Accept }\end{array}$} & 0.1500 & 0.6000 & & $-2.82 \mathrm{E}-13$ \\
\hline & & $(0.06942)$ & $(0.217352)$ & 0.6617 & $(-0.00000328)$ \\
\hline & & No & No & & \\
\hline & & 0.1500 & 0.6000 & & $-2.27 \mathrm{E}-12$ \\
\hline H13: Japan & No/Failed to & $(0.110935)$ & $(0.187422)$ & 0.8751 & $(-0.000346)$ \\
\hline & & No & No & & \\
\hline
\end{tabular}




\begin{tabular}{|c|c|c|c|c|c|}
\hline \multirow{3}{*}{ H14: Malaysia } & \multirow{3}{*}{$\begin{array}{c}\text { No/Failed to } \\
\text { Accept }\end{array}$} & 0.1500 & 0.6000 & \multirow{3}{*}{0.1472} & $-1.23 \mathrm{E}-13$ \\
\hline & & $(0.171103)$ & $(0.281828)$ & & $(-0.00000443)$ \\
\hline & & No & No & & \\
\hline \multirow{3}{*}{ H15: Mexico } & \multirow{3}{*}{$\begin{array}{c}\text { No/Failed to } \\
\text { Accept }\end{array}$} & 0.1500 & 0.6000 & \multirow{3}{*}{0.1030} & $-7.52 \mathrm{E}-14$ \\
\hline & & $(0.124779)$ & $(0.341921)$ & & $(-0.00000469)$ \\
\hline & & No & No & & \\
\hline \multirow{3}{*}{ H16: Poland } & \multirow{3}{*}{$\begin{array}{c}\text { No/Failed to } \\
\text { Accept }\end{array}$} & 0.1500 & 0.6000 & \multirow{3}{*}{0.5790} & $-7.27 \mathrm{E}-13$ \\
\hline & & $(0.148927)$ & $(0.174457)$ & & $(-0.0000477)$ \\
\hline & & No & No & & \\
\hline \multirow{3}{*}{ H17: Romania } & \multirow{3}{*}{$\begin{array}{c}\text { No/Failed to } \\
\text { Accept }\end{array}$} & 0.1500 & 0.6000 & \multirow{3}{*}{0.8696} & $1.32 \mathrm{E}-12$ \\
\hline & & $(0.09066)$ & $(0.107679)$ & & $(0.0000973)$ \\
\hline & & No & No & & \\
\hline \multirow{3}{*}{ H18: Russia } & \multirow{3}{*}{$\begin{array}{c}\text { No/Failed to } \\
\text { Accept }\end{array}$} & 0.1500 & 0.6000 & \multirow{3}{*}{0.7510} & $5.16 \mathrm{E}-13$ \\
\hline & & $(0.137969)$ & $(0.117633)$ & & $(0.0000148)$ \\
\hline & & No & No & & \\
\hline \multirow{3}{*}{ H19: South Africa } & \multirow{3}{*}{$\begin{array}{c}\text { No/Failed to } \\
\text { Accept }\end{array}$} & 0.1500 & 0.6000 & \multirow{3}{*}{-0.0449} & $-1.38 \mathrm{E}-13$ \\
\hline & & $(0.112948)$ & $(0.133079)$ & & $(-0.000178)$ \\
\hline & & No & No & & \\
\hline \multirow{3}{*}{ H20: South Korea } & \multirow{3}{*}{$\begin{array}{c}\text { No/Failed to } \\
\text { Accept }\end{array}$} & 0.1500 & 0.6000 & \multirow{3}{*}{0.2151} & $-1.23 \mathrm{E}-13$ \\
\hline & & $(0.077137)$ & $(0.200092)$ & & $(-0.0000142)$ \\
\hline & & No & No & & \\
\hline \multirow{3}{*}{ H21: Spain } & \multirow{3}{*}{$\begin{array}{c}\text { No/Failed to } \\
\text { Accept }\end{array}$} & 0.1500 & 0.6000 & \multirow{3}{*}{0.8564} & $-4.11 \mathrm{E}-13$ \\
\hline & & $(0.095189)$ & $(0.346363)$ & & $(-0.0000249)$ \\
\hline & & No & No & & \\
\hline \multirow{3}{*}{ H22: Taiwan } & \multirow{3}{*}{$\begin{array}{c}\text { No/Failed to } \\
\text { Accept }\end{array}$} & 0.1500 & 0.6000 & \multirow{3}{*}{0.6225} & $-9.6 \mathrm{E}-14$ \\
\hline & & $(0.157178)$ & $(0.182356)$ & & $(-0.00000548)$ \\
\hline & & No & No & & \\
\hline \multirow{3}{*}{ H23: Turkey } & \multirow{3}{*}{$\begin{array}{c}\text { No/Failed to } \\
\text { Accept }\end{array}$} & 0.1500 & 0.6000 & \multirow{3}{*}{0.6630} & $6.42 \mathrm{E}-13$ \\
\hline & & $(0.178044)$ & $(0.271925)$ & & $(0.000169)$ \\
\hline & & No & No & & \\
\hline & & 0.1500 & 0.6000 & & $2.27 \mathrm{E}-13$ \\
\hline H24: Ukraine & No/Failed to & $(0.136569)$ & $(0.267014)$ & 0.5505 & $(0.000011)$ \\
\hline
\end{tabular}




\begin{tabular}{|c|c|c|c|c|c|}
\hline & Accept & No & No & & \\
\hline \multirow{3}{*}{$\begin{array}{l}\text { H25: United } \\
\text { Kingdom }\end{array}$} & \multirow{3}{*}{$\begin{array}{c}\text { No/Failed to } \\
\text { Accept }\end{array}$} & 0.1500 & 0.6000 & \multirow{3}{*}{0.3383} & $-3.13 \mathrm{E}-12$ \\
\hline & & $(0.097314)$ & $(0.133279)$ & & $(-0.000394)$ \\
\hline & & No & No & & \\
\hline \multirow{3}{*}{ H26: United States } & \multirow{3}{*}{$\begin{array}{c}\text { No/Failed to } \\
\text { Accept }\end{array}$} & 0.1500 & 0.6000 & \multirow{3}{*}{0.6929} & $-1.35 \mathrm{E}-12$ \\
\hline & & $(0.155606)$ & $(0.419879)$ & & $(-0.0000511)$ \\
\hline & & No & No & & \\
\hline
\end{tabular}

\section{Presence of Bubbles and volatility in automobile industry market shares via ARCH term}

The findings as shown in above table 2 confirms that there is no ARCH term found significant in series of total market shares of automobile industry (cars) of all selected 26 nations in the presence of proxies of equity / stock markets, as Z stats was found less than 2 (non significant) for all of the mentioned cases. As a result, we fail to accept all two statements of hypotheses under the stated proposition for ARCH term which are: there is volatility in Automobile industries (cars) total market shares in the presence of change in stock prices for top automobile manufacturing nations and there is volatility in Automobile industry (cars) total market shares in the presence of trading volumefor top automobile manufacturing nations, for $\mathrm{ARCH}$ term.

\section{Presence of Bubbles and viscosity in automobile industry market shares via GARCH term}

The findings as shown in above table confirms that there is no GARCH term found significant in series of total market shares of automobile industry (cars) of all selected 26 nations in the presence of proxies of equity / stock markets as Z stats was found less than 2 (non significant) for all of the mentioned cases.

As a result, we fail to accept all two statements of hypotheses under the stated proposition for GARCH term which are: there is volatility in Automobile industry (cars) total market shares in the presence of change in stock pricesfor top automobile manufacturing nations and there is volatility in Automobile industry (cars) total market shares in the presence of trading volumefor top automobile manufacturing nations for GARCH term.

\section{Hypotheses Assessment Summary}

Table 3

Proposition: Are the volatility in automobile industry (Cars) total market share of the world (top automobile industry manufacturing countries) same in the presence of financial fundamentals (equity/ stock markets)? 
Statement of Hypothesis: There is the volatility in the total market share of automobile industry (cars) of top automobile industry manufacturing countries in the presence of change in stock prices.

\begin{tabular}{|c|c|c|c|c|c|c|c|c|c|c|c|}
\hline & \multicolumn{2}{|c|}{$\mathrm{EC}$} & & \multicolumn{2}{|c|}{$\mathrm{EC}$} & & \multicolumn{2}{|c|}{$\mathrm{EC}$} & & \multicolumn{2}{|c|}{$\mathrm{EC}$} \\
\hline & $\mathrm{ARCH}$ & GARCH & & $\mathrm{ARCH}$ & GARCH & & $\mathrm{ARCH}$ & GARCH & & $\mathrm{ARCH}$ & GARCH \\
\hline $\begin{array}{l}\text { H1: AR- } \\
\text { GENTINA }\end{array}$ & FTA & FTA & $\begin{array}{l}\text { H8: GER - } \\
\text { MANY }\end{array}$ & FTA & FTA & $\begin{array}{c}\text { H15: } \\
\text { MEXICO }\end{array}$ & FTA & FTA & $\begin{array}{c}\text { H22: } \\
\text { TAIWAN }\end{array}$ & FTA & FTA \\
\hline $\begin{array}{l}\text { H2: AUS- } \\
\text { TRALIA }\end{array}$ & FTA & FTA & $\begin{array}{l}\text { H9: HUN- } \\
\text { GARY }\end{array}$ & FTA & FTA & $\begin{array}{c}\text { H16: } \\
\text { POLAND }\end{array}$ & FTA & FTA & $\begin{array}{c}\text { H23: } \\
\text { TURKEY }\end{array}$ & FTA & FTA \\
\hline H3: BRAZIL & FTA & FTA & H10: INDIA & FTA & FTA & $\begin{array}{l}\text { H17: } \\
\text { ROMA- } \\
\text { NIA }\end{array}$ & FTA & FTA & $\begin{array}{c}\text { H24: } \\
\text { UKRAINE }\end{array}$ & FTA & FTA \\
\hline $\begin{array}{c}\text { H4: CANA- } \\
\text { DA }\end{array}$ & FTA & FTA & $\begin{array}{l}\text { H11: IN- } \\
\text { DONESIA }\end{array}$ & FTA & FTA & $\begin{array}{l}\text { H18: } \\
\text { RUSSIA }\end{array}$ & FTA & FTA & $\begin{array}{c}\text { H25: } \\
\text { UNITED } \\
\text { KING- } \\
\text { DOM }\end{array}$ & FTA & FTA \\
\hline H5: CHINA & FTA & FTA & H12: ITALY & FTA & FTA & $\begin{array}{c}\text { H19: } \\
\text { SOUTH } \\
\text { AFRICA }\end{array}$ & FTA & FTA & $\begin{array}{c}\text { H26: } \\
\text { UNITED } \\
\text { STATES }\end{array}$ & FTA & FTA \\
\hline $\begin{array}{l}\text { H6: CZECH } \\
\text { REPUBLIC }\end{array}$ & FTA & FTA & H13: JAPAN & FTA & FTA & $\begin{array}{c}\text { H20: } \\
\text { SOUTH } \\
\text { KOREA }\end{array}$ & FTA & FTA & & & \\
\hline H7: FRANCE & FTA & FTA & $\begin{array}{l}\text { H14: MA- } \\
\text { LAYSIA }\end{array}$ & FTA & FTA & $\begin{array}{l}\text { H21: } \\
\text { SPAIN }\end{array}$ & FTA & FTA & & & \\
\hline
\end{tabular}

Statement of Hypothesis is failed to reject if $\mathrm{z}$-value $>2$

$\mathrm{EC}=$ Empirical Conclusion; FTR= Failed to Reject; FTA=Failed to Accept

The ARCH term and GARCH term are not significant in the series of total market share of automobile industrys (cars) of top automobile industry manufacturing countries in the presence of change in stock prices, thus the volatilities in automobile industry (Cars) total market share of the world (top automobile industry manufacturing countries) are not found present at all in the stated conditional variable.

Statement of Hypothesis: There is the volatility in the total market share of automobile industry (cars) of top automobile industrys manufacturing countries in the presence of trading volume of stocks.

\begin{tabular}{|c|c|c|c|c|c|c|c|c|c|c|c|}
\hline & \multicolumn{2}{|c|}{$\mathrm{EC}$} & & \multicolumn{2}{|c|}{$\mathrm{EC}$} & & \multicolumn{2}{|c|}{$\mathrm{EC}$} & & \multicolumn{2}{|c|}{$\mathrm{EC}$} \\
\hline & $\mathrm{ARCH}$ & GARCH & & $\mathrm{ARCH}$ & GARCH & & $\mathrm{ARCH}$ & GARCH & & $\mathrm{ARCH}$ & GARCH \\
\hline $\begin{array}{l}\text { H1: AR- } \\
\text { GENTINA }\end{array}$ & FTA & FTA & $\begin{array}{l}\text { H8: GER- } \\
\text { MANY }\end{array}$ & FTA & FTA & $\begin{array}{c}\text { H15: } \\
\text { MEXICO }\end{array}$ & FTA & FTA & $\begin{array}{c}\text { H22: } \\
\text { TAIWAN }\end{array}$ & FTA & FTA \\
\hline $\begin{array}{l}\text { H2: AUS- } \\
\text { TRALIA }\end{array}$ & FTA & FTA & $\begin{array}{l}\text { H9: HUN- } \\
\text { GARY }\end{array}$ & FTA & FTA & $\begin{array}{c}\text { H16: } \\
\text { POLAND }\end{array}$ & FTA & FTA & $\begin{array}{c}\text { H23: } \\
\text { TURKEY }\end{array}$ & FTA & FTA \\
\hline H3: BRAZIL & FTA & FTA & H10: INDIA & FTA & FTA & $\begin{array}{l}\text { H17: } \\
\text { ROMA- } \\
\text { NIA }\end{array}$ & FTA & FTA & $\begin{array}{c}\text { H24: } \\
\text { UKRAINE }\end{array}$ & FTA & FTA \\
\hline $\begin{array}{c}\text { H4: CANA- } \\
\text { DA }\end{array}$ & FTA & FTA & $\begin{array}{c}\text { H11: IN- } \\
\text { DONESIA }\end{array}$ & FTA & FTA & $\begin{array}{c}\text { H18: } \\
\text { RUSSIA }\end{array}$ & FTA & FTA & $\begin{array}{l}\text { H25: } \\
\text { UNITED } \\
\text { KING- } \\
\text { DOM }\end{array}$ & FTA & FTA \\
\hline H5: CHINA & FTA & FTA & H12: ITALY & FTA & FTA & $\begin{array}{c}\text { H19: } \\
\text { SOUTH } \\
\text { AFRICA }\end{array}$ & FTA & FTA & $\begin{array}{c}\text { H26: } \\
\text { UNITED } \\
\text { STATES }\end{array}$ & FTA & FTA \\
\hline
\end{tabular}




\begin{tabular}{|c|c|c|c|c|c|c|c|c|c|c|}
\hline $\begin{array}{c}\text { H6: CZECH } \\
\text { REPUBLIC }\end{array}$ & FTA & FTA & H13: JAPAN & FTA & FTA & $\begin{array}{c}\text { H20: } \\
\text { SOUTH } \\
\text { KOREA }\end{array}$ & FTA & FTA & & \\
\hline H7: FRANCE & FTA & FTA & $\begin{array}{c}\text { H14: MA- } \\
\text { LAYSIA }\end{array}$ & FTA & FTA & $\begin{array}{c}\text { H21: } \\
\text { SPAIN }\end{array}$ & FTA & FTA & & \\
\hline
\end{tabular}

Statement of Hypothesis is failed to reject if $\mathrm{z}$-value $>2$

$\mathrm{EC}=$ Empirical Conclusion; FTR= Failed to Reject; FTA=Failed to Accept

The ARCH term and GARCH term are not significant in the series of total market share of automobile industry's (cars) of top automobile industry's manufacturing countries in the presence of trading volume of stocks, thus the volatilities in automobile industry (Cars) total market share of the world (top automobile industry's manufacturing countries) are not found present at all in the stated conditional variable.

\section{Discussion and Conclusion}

The findings confirmed that there is no GARCH 1,1 process in any of the given series as the $\mathrm{ARCH}$ and GARCH terms are found insignificant in the presence of stated conditional variables. In other words, the lagged autoregressive investigation of this research has revealed that econometrical volatilities in the stated market shares defined over previous time grid don't significantly predict volatility defined during current time grid for all the nations when their financial fundamentals (change in stock prices and trading volumes) were taken as the conditional variables. In contrast to the findings of this research, the findings in the extant literature reported that there is the volatile behavior of automobile markets in terms of their sales for the automobile manufacturing giants i.e. USA and Germany when the diverse economic factors are taken as the controlled variables.

According to the main findings of this study, this paper suggests that financial fundamentals will not be bringing any state of change in trends of market share for top automobile manufacturing nations and it will continue for further several years.

\section{References}

Bala, A. and Mukund, K.S. (2001). Interrelationship between Indian and US stock markets. Journal of Management Research, 1(3), 141-8.

Batareddy, M., Gopalaswamy, A.K., \& Huang, C. (2012). The stability of long-run relationships: A study on Asian emerging and developed stock markets (Japan and US). International Journal of Emerging Markets,7(1), 31 - 48

Bell, D.D., Keeney, R.L., \& Little, J, D. C. (1975). A Market Share Theorem. Journal of Marketing Research, 12(2),136-141. 
Benka, S., \& Krist, B. (2014). The Auto Industry Has a Lot at Stake in TPP and TTIP. Retrieved from http://americastradepolicy.com/the-auto-industry-has-a-lot-at-stake-in-tpp-and-ttip/

Bessler, D.A. \& Yang, J. (2003). The structure of interdependence in international stock markets. Journal of International Money and Finance, 22(2), 261-87.

Bodla, B.S. \& Turan, M.S. (2006). Interlinkage dynamics of Asian stock markets. P.U.Management Review, 16(1), 20-34.

Boyle, S. E., \& Hogarty, T. F. (1975). Pricing Behavior in the American Automobile Industry, 1957-71. The Journal of Industrial Economics, 24.

Chan, K.C., Gup, B.E. \& Pan, M.S. (1997). International stock market efficiency and integration, a study of eighteen nations. Journal of Business Finance \& Accounting, 24(6), 803-13.

Chaudhuri, K. (1997). Co-integration, Error correction and Granger causality: An application with Latin American stock markets. Applied Economics Letters, 4(8), 469-71.

Copeland, A, Wendy, D \& George, Hall. (2005). Prices, Production and Inventories, over the Automobile industry Model Year. Working Paper 11257, NBER.

Corhay, A., Rad, A.T. \& Urbain, J.P. (1995). Long run behavior of Pacific-Basin stock prices. Applied Financial Economics, 5(1), 11-18.

Daly, K.J. (2003). Southeast Asian stock market linkages evidence from pre and post October 1997. ASEAN Economics Bulletin, 20(1), 73-85.

Darrell, J., (2015). General Motors Company May be the Most Compelling Auto Turnaround Stories in our Universe: Citi. Retrieved from http://www.bidnessetc.com/35563-general-motors-companymay-be-the-most-compelling-auto-turnaround-stories-i/

Elyasiani, E., Perera, P. \& Puri, T.N. (1998). Interdependence and dynamic linkages between stock markets of Sri Lanka and its trading partners. Journal of Multinational Financial Management, $8(1), 89-101$.

Fogg, C., D. (1974). Planning Gains in Market Share. Journal of Marketing, 38(03),30-38.

Goldberg, P.(1995). Imperfect competition in international markets: The case of the U.S. automobile industry. Econometrica, 63(4), 891-951.

Gooijer, J.G.D. \& Sivaraja, S. (2008). Parametric and nonparametric granger causality testing: linkages between international stock markets. Physica A, 387(11), 2547-2560.

Gomes, C. (2014). Global Auto Report. Global Economics, Scotiabank. 
Hoffer, G., Marchand, J., \& Albertine, J. (1976). Pricing in the Automobile Industry: A Simple Econometric Model. Southern Economic Journal, 43(1), 948-951

Hoque, H.A.A.B. (2007). Co-movement of Bangladesh stock market with other markets. Managerial Finance, 33(10), 814-6.

Kim, S.J. (2005). Informational leadership in the advanced Asia-Pacific stock markets: return,volatility and volume information spillovers from the US and Japan. Journal of the Japanese and International Economies, 19(3), 338-65.

Klink, G., Mathur, M., Kidambi, R. \& Sen, K. (2013). The contribution of the automobile industry to technology and value creation. Retrieved from https://www.atkearney.com/paper//asset_publisher/dVxv4Hz2h8bS/ content/id/2427536

Kurihara, Y., \& Nezu, E. (2006). Recent stock price relationships between Japanese and US stock markets, Studies in Economics and Finance, 23(3), 211 - 226

Kwoka, J.E. Jr,. (1984). Market Power and Market Change in the U.S. Automobile Industry. The Journal of Industrial Economics, 32(4), 509-522

Masih, A.M.M. \& Masih, R. (1997). Dynamic linkages and the propagation mechanism driving major international stock markets: an analysis of the pre- and post-crash eras. The Quarterly Review of Economics and Finance, 37(4), 859-85.

Mazzucato, M. \& Semmler, W. (2002). The Determinants of Stock Price Volatility: An Industry Study. Nonlinear Dynamics, Psychology, and Life Sciences, 6, 230-253

Menon, R.N., Subha, M.V. \& Sagaran, S. (2009). Co-integration of Indian stock markets with other leading stock markets. Studies in Economics and Finance, 26(2), 87-94.

Mukherjee, K.N. \& Mishra, R.K. (2007). International stock market integration and its economic determinants: a study of Indian and world equity market. Vikalpa, 32(4), 29-34.

Nath, G.C. \& Verma, S. (2003). Study of common stochastic trend and co-integration in the emerging markets: A case study of India, Singapore and Taiwan, Research paper, NSE-India.

OECD Stat (2015). Economic Indicators Statistics. http://stats.oecd.org/Index.aspx .

Pan, M.S., Liu, Y.A. and Roth, H.J. (1999). Common stochastic trends and volatility in Asian-Pacific equity markets. Global Finance Journal, 10(2), 161-72.

Shamsuddin and Kim. (2008). Integration and interdependence of stock and foreign exchange markets: An Australian perspective. Journal of International Financial Markets Institutions and Money, 13(3), 237-254

Sharma, G.D., \& Bodla, B.S. (2011). Inter-linkages among stock markets of South Asia. Asia-Pacific Journal of Business Administration, 3(2), $132-148$

Sharma, S.C. \& Wongbangpo, P. (2002). Long-term trends and cycles in ASEAN stock markets. Review of Financial Economics, 11(4), 299-315. 
Siddiqui, S. (2009a). Examining Association between S\&P CNX Nifty and selected Asian and US stock markets. Retreived from www.nseindia.com/content/research/res_paperfinal235.pdf

Tan, Y., Shen, L., \& Langston, C. (2012).A casual relationship between building maintenance Market and GDP:Hong Kong study. Journal of Facilities Management, 10(3), 241 -251.

Thompson, P.A., \& Noordewier, T. (1992).Estimating the Effects of Consumer Incentive Programs on Domestic Automobile Sales. Journal of Business \& Economic Statistics, 1992, 10(4), 409-17.

United Nations, Department of Economic and Social Affairs, Population Division (2015). World Population Prospects: The 2015 Revision, Key Findings and Advance Tables. Working Paper No. ESA/P/WP.241.

Wething, H., \& Scott, E.R. (2012). Jobs in the U.S. auto parts industry are at risk due to subsidize and unfairly traded Chinese auto parts: Trade and Globalization. Retrieved from http://www.epi.org/publication/bp336-us-china-auto-parts-industry/

Worthington, A.C., Katsuura, M. \& Higgs, H. (2003). Price linkages in Asian equity markets: evidence bordering the Asian economic, currency and financial crises. Asia-Pacific Financial Markets, $10(1), 29-44$.

Yang, J., Kolari, J.W. \& Min, I. (2003). Stock market integration and financial crises: The case of Asia. Applied Financial Economics, 13(7), 477-86.

Yang, J., Kolari, J.W. \& Sutanto, P.W. (2004). On the stability of long-run relationships between emerging and US stock markets. Journal of Multinational Financial Management, 14(3), $233-48$.

Yia, Z, Heng, C., \& Wong, W.K. (2009). China's Stock Market Integration with a Leading Power and a Close Neighbor. Journal of Risk Financial Management, 2(1), 38-74; doi:10.3390/jrfm2010038 School of Finance Southwestern, University of Finance and Economics.

Zack, G. (2014). Falling Oil Prices to Benefit Ford Motor, General Motors, But Not Tesla Motors. Retrieved from http://www.bidnessetc.com/31311-falling-oil-prices-to-benefit- ford-motorgeneral-motors-but-not-tesla-motor/ 